\title{
Implementation of Local Cultural Value in Character Education Program Supervision
}

\author{
Nanik Hindaryatiningsih \\ University Of Halu Oleo Kendari, Southeast Sulawesi, Indonesia
}

\begin{abstract}
The purpose of this research was knowing Buton culture values which practiced in the planning of the value of education. This study used an ethnographic qualitative approach method conducted at SMAN 2 Baubau, Southeast Sulawesi in 2016. The data were collected by using In-depth interview techniques, documentations review, and Participant observation (descriptive bservation, focused observation, and selected observation). The focus of observation was on cultural events and Interactive the informants' behavior. The informants of this research Consist of principal, teachers, administrative staff of the school, school committees, students, parents, community leaders, and traditional leaders. The techniques of the data analyze was using Spradley' technique (Domain analysis, taxonomy, componential, and Themes analysis). The finding Showed that (1) the main values in a culture "pomae-maeka" on Buton society, consisting of: the value of honesty and the value of justice, (2) cultural values of "pomae-maeka" practiced in character Education supervision.
\end{abstract}

Keywords: local culture value, character education, supervision

\section{Introduction}

Today, Indonesian nation is experiencing a moral crisis either among the adult or adolescent community. Among adolescents, the tendency to have free sex, the use of drugs and alcohol occurs in big cities to areas such as the city of Baubau Southeast Sulawesi. In schools that should be a learning center of value, there is a lack of discipline, dishonesty / cheating, cheating culture, lack of manners and respect for teachers. Recalcitrant pupils, mischievous, dislike knowledge, often exhibit imitative, manipulative, consumptive and desperate behavior. (Mu'in, 2011: 28).

These symptoms indicate that education has not been able to change the behavior of the nation's children for the better. Moral degeneration in the dimensions of character occurring in the world of education may be the access of the transitional process from the traditional to the modern era. This framework of thought is a logical consequence of what Rahim said, that "in modern society the traditional values, however great, easily threatened (2011: 24-25) ".

There are two aspects that need to be considered in facing the dilemma above, namely cultural aspect and character aspect in education. Fukuyama argued that the characteristic of a society that has an advantage in today's global competition is not competition between ideologies, but the competition between countries with high social capital (high trust society) (1996: 25-26). Similar assertions were made by several experts, including Lawrence Harrison, Robert Kaplan, Seymor Martin Lipset, Robert Putman, Thomas Sowell and Sammuel P. Huntington stated that the key to success of a country is determined by a country that has a conducive culture (2000: xiv) . The views of these experts, asserted that culture plays an important role on the progress of a nation. The progress and future of the nation is determined by the young generation.

The young generation is a national asset that must be maintained and guided so that they can learn the goodness of their environment. Therefore, in dealing with character issues that occur among the younger generation today, it should use a culture-based character education approach. Bennet,stated that character education as "Cultivating the virtues through the formation of good habits" (1999: 525). Children need to be accustomed to always do well. Virtue values are formed from the environment in which the child is located. Lickona suggested that the character education cannot function in a vacuum, it requires a social environment "character does not function in a vacuum, it functions in a social environment" (1992: 12-22). In this case, Brooks agreeing with the values contained in learning should be a collection of virtues. Therefore the character education program must be relevant to the curriculum containing moral values. According to Colgan (2003), character education programs must be relevant to the curriculum, there has to be some connection between morality and the curriculum.

In Indonesia, within certain limits has been done since the curriculum of 1947 which contains subjects of character education that coherent content with character education, until the curriculum of 2013 with the condition of character education content in all school activities. Although there is a curriculum about character education in schools, but in reality the character education until now has not been done as expected. 
There are several causes of character education in schools have not been able to run optimally. First, due to the lack of monitoring and evaluating the implementation of character education programs that have been established school. Supervision is the process to see how far the level of conformity between the implementation with the plan of character education programs that have been set, while the evaluation to see how far the results of the implementation of character education programs affect the changes in student behavior. Second, imbalances in school programs. Programs in schools focus more on intellectual development or cognitive aspects than on developing the attitudes and behaviors of learners. Teaching teaching practices are more likely to achieve academic knowledge, and ignoring the problem characters. Whereas teach character values must As important as teaching science. As proposed by Gray (2009: 1), teaching character should be just as important as teaching academics. Society will continue to be in a state of cha o $s$ is character until taught in school again. In this way of education can be used as a way to significantly Decrease moral decay over taking from society. Teaching is a reflection of the morality of society, so education $s$ inevitably Caught Up in moral debate. Moving from the above thinking, the school is a vehicle to change the behavior of students from bad to good, conditioned students to understand the good, feel good and practice it in life.

Conditioning students to do well depends on how schools create a good climate / culture, and how schools prepare well-meaning educators and staff. Lickona argues that to change the behavior of moral students begins with how schools form the school culture (1992: 325). In broad outline it is said that there are six elements for determining the positive morality of school culture that is: (a) moral academic leadership, (b) the school can be a model of discipline, showing values in all school environments, (c) schools are like a community, ) The students feel that the school is theirs, be careful and make the school the best, (e) a healthy atmospheric climate, peer relations, respectful, friendly and familial, (f) any school expenditure costs are used for concentration on moral formation. The relevant opinion is said by Suparno, that which needs to be evaluated from values education or character is the process of planting the value is said to be really successful if the student changes for the better in terms of value (2010: 321).

This understanding, giving the conclusions that need to be monitored and assessed from the implementation of character education programs is the character of the school, the function of school staff as value educators, and the extent to which students manifest good values. Important school characters are of particular concern to prevent schools from criminal practices at school. Luddin describes school crime, among others, such as: principals and teachers who give exam answers; Translate questions and answer first; Chat value and pass the child to get the rank predicate; Justifies the additional money search by deliberately not expending the content of the learning materials; New admissions practices; And teacher conflicts that are more due to the mastery of resources (2005: 123-126).

If the problem students and school institutions are also problematic, then to prevent it so that no further required role and commitment of the principal in conducting the supervision and evaluation of character education. Monitoring and evaluation system should be done according to the cultural values of the community. How the organization of school activities that internalize the noble values of society can provide examples of good practices of organizational management practices in learners. In this case prepare them as leaders on the future.

Research on local cultural values applied in schools and in government and used as a reference source of value, has been studied and researched many people. Within the scope of the school include the research of Ekosusilo (2003) which found that the universal elements of culture can establish a value system in the organizational culture of the school at three superior primary schools in Malang, the Hindaryatiningsih (2013) study that found the application of the cultural value of Buton in educational planning Grades in school and according to Viadero (2007), many studies of character education programs can have a positive effect on academic and social development. While in the governmental level, Tamrin (2016), found cultural values plays an important role to the successful development of Baubau city of Southeast Sulawesi.

The results of this study indicate that with the approach of cultural values, proved effective in addressing social problems in society. The Buton Society, for example, has demonstrated its efficacy in reducing conflict. Since the first they know and have been practicing a system of values and philosophy of life bhinci-bhinciki porters who teaches every human being to do the four principles (sara pataanguna), namely Love each other, respect each other, fear each other, and keep each other with each other. (Tamrin, 2016, Hindaryatiningsih, 2013, Rudyansyah, 2010). Cultural values have been proven effective can be used as a means of intelligence of the younger generation. Rahyono (2009: 7), said that the values of cultural wisdom is something that has been generated by the community that can be used by others as a means to educate. According to Colquitt et.al (2009: 292), "cultural values, defined as the shared beliefs about desirable end states or modes of conduct in a given culture". If so, the cultural values of Buton should be referred to as the value developed in carrying out character education in schools in Buton, among others, in Baubau City. 
Based on the description above, the purpose of this research is to assess: (1) primary values in the culture "pomae-maeka", and (2) the implementation of cultural values "pomae-maeka" under the supervision of character education programs in schools .

\section{Literature Review}

\section{Local Culture}

The term local culture is commonly used to characterize the experience of everyday life in specific, identifiable localities. It reflects ordinary people's feelings of appropriateness, comfort, and correctnessattributes that define personal preferences and changing tastes. Local culture provides a sense of identity for communities and residents. This identity facilitates common understandings, traditions, and values that are all central to identifying plans of action to improve well-being. Culture contributes to building a sense of local identity and solidarity. It influences the confidence that communities have for coming together to address specific needs and problems. This local commitment among residents, regardless of economic or political conditions, can serve as a valuable tool in shaping the effectiveness of development options and local actions. Such commitment, based on culture and common identity, can be seen as a potentially important tool in sustaining local government, development, and social improvement efforts.

\section{Character Education}

Character education is the intentional, proactive effort by schools, districts, and states to instill in their students important core, ethical values such as caring, honesty, fairness, responsibility, and respect for self and others.

Character education is any deliberate approach by which school personnel, often in conjunction with parents and community members, help children and youth become caring, principled, and responsible (ASCD formerly Association for Supervision and Curriculum Development)

\section{Methodology}

The method used in this study is a qualitative method of ethnography study type because it aims to know the cultural events and interactions of natural behavior of people observed in the study. Data in the form of words or sentences in the form of information and activities or actions of people who become informants, and the atmosphere at SMAN 2 Baubau related to cultural values "pomae-maeka" which is implemented under the supervision of character education. Data and information were collected through in-depth interviews with informants, participant observation, and documentation studies. The steps of research developed from this line of thought Spradley (1997: 181), namely: first, do a grand tour of observation to get a general overview of the research context; second, analysis initial findings and determine the focus of the study; Third, do a mini tour of observation to dig deep meaning of the focus has been selected; Fourth, perform data analysis, fifth, concluding the results of research and pour in the report. In analyzing the data the researcher uses Spradley's suggested analysis (1997: 139-262), namely: (1) domain analysis, (2) taxonomic analysis, (3) component analysis, and (4) theme analysis. Validity checks data using several criteria, namely: (1) validity, (2) transferability, (3) dependability, and (4) conformability.

\section{Result and Discussion}

Result

From the research data can be presented findings of the study, including: first, Noble values culture "pomae-maeka" is a philosophy of life Buton Buton and has been practiced since the days of the empire. Literally the term pomae-maeka means "mutual fear". The meaning of fear in the philosophy of the people of Buton is defined as fear of wrongdoing, fear of breaking the rules and fear of misusing authority. If interpreted in depth then every human action is based on the principle pomae-maeka, then that person will always hold fast to the values of kindness. Values in pomae-maeka in the context of supervision is a basic principle held by the nine ministers of the empire "sio limbona" In exercising oversight on the laws of the Sultanate. The principle of upholding the truth and not abusing this authority is used by the sultanate's devices in performing its duties as a legislative body that is obliged to oversee the course of government.

At the level of praxis, according to some community leaders and cultural figures who became an informant for the study, during the sultanate of supervision carried out with the aim, among others: (a) to determine whether the sara sultanate run the government in accordance with law, (b) know all Issues that cause people to violate any applicable rules or regulations. If so, the overall object of supervision include: (1) the attitude and behavior of the sara (sultanate officials) in carrying out the law; (2) attitudes and behavior of the general public in complying with the law. 
From the analysis of data in the field, the noble values in the culture "pomae-maeka" Buton contains two main didactic value, ie the value of honesty and justice. The value of justice can be seen in the way sio limbona minister in supervising public behavior generally indiscriminately both officials of the empire (the sultan, sapati, kenepulu, and kapitalao) or Papara people (ordinary people). In the general public the Papara, sio limbona instill manners and gave the example of the good. At the sultanate officials, sio limbona supervise all the movements and behavior of the sara sultanate in running the government. Close supervision is conducted day and night, covering behavior (gestures), speech (language), and fairy dress (dress mode).Monitoring methods are done by observing, reminding, teaching and advising. If not heeded his advice, the minister sio limbona entitled to curse the person. The oath is said to bring misery to the person concerned.

Furthermore, the value of honesty can be seen on ways to assess a person's behavior that can be observed on ways of enforcing the rules and awards. The Sultanate administration does an honest assessment / evaluation. The people and government officials are entitled to an honest assessment. Ratings for the less commendable behavior violates the law will get the customary courtesy bhitara judicial process. Bhitara implementation of the authority of the judiciary held by kenepulu. Nevertheless, its implementation remains supervised and controlled by the sio limbona minister. The aim is that cases tried by the judiciary of "kenepulu" are not exchanged between good and right. The cases that were tried are behaviors that are less commendable / undignified, like: Sabara gau, lempagi, pulu mosala tee mingku mosola, and pebula. Bhitara (decide a case) is carried out through three stages: straightening correct and binding firm that has not changed, and decide sanctions. That is, in carrying out bhitara, sara sultanate is not justified exchanging between good and truly a case. Bhitara the result was fair, there are some officials who sanctioned the empire, among others: pasabu (dismissal), papacy (exile), tatasi pulanga (disenfranchisement of an officer for seven generations), and gogoli (the death penalty). In addition, providing an assessment of poor behavior, the state also provides good behavior assessment. The state is entitled to reward each person as much as the virtues it does, for example: his courage, his piety, the sacrifice of his possessions, and his ingenuity. Award received, in the form of improvement of welfare, a plot of land, position, and position.

Justice and honesty in the supervision and evaluation of the sultanate have given the example and value. Honesty is done on monitoring and evaluation at the time of the empire teach every person to enforce the rules honestly, giving punisment for Who do not obey the rules or behave improperly, but also provide a deterrent effect. While the reward system for people who abide by the rules or behaves well, can motivate everyone to get it.

The second discovery, implementation of cultural values in the "pomae-maeka" was found in the way the principal in conducting surveillance of character education program fairly and indiscriminately. The value of justice appears in the supervision of behaviors imposed by principals not only for learners, but teachers / staff / employees including self-principals themselves are also supervised. Observed behavior, including speech, dress, and attitude / gestures. Supervision is done regularly and continuously either in class or in school by observing, rebuking, reminding, advising. In addition, the principal does so in a non-formal, relaxed and friendly manner.

In addition to the value of justice, supervision is also done honestly. The value of honesty appears in the principal's way of conducting evaluations that emphasize honesty to teachers in providing a rule-based assessment. Students are entitled to an honest and objective assessment of their behavior and attitudes. The students are also entitled to be rewarded for achievement and positive behavior (His skill, moral, speak). Award received in the form of money, a charter, become a superior student and a good raport value (personality value). Honest judgments are seen in the objective standards used by schools both in terms of giving a "score" of offense or the value of "personality". The value of personality in report cards (poor, good, and excellent) is the result of continuous observations made by all teachers administered by homeroom teachers, religious teachers, civic teachers and determined by educator board meetings, including student behavior (noble character and how to dress). Noble deeds are judged, among others, discipline, cleanliness, health, responsibility, courtesy, confidence, competitiveness, social relationships, honesty, and the implementation of ritual worship.

Not only is the award given by the school, the school also impose sanctions for every student or school personnel who behave poorly (insulting and disrespectful words, disrespectful dress, bad behavior and temperament, and bad words). This can be observed in the enforcement of applicable rules / disciplines and awards. Rules / disciplines of the school are enforced indiscriminately. Who will be guilty of sanctions. Sanctions received by students, in the form of: suspension, summoning, expelled from school and the value of report cards are not good (value of personality). Sanctions received by teachers and employees are in the form of reprimands and warning letters.

The findings of this study can be seen in the figure below. 


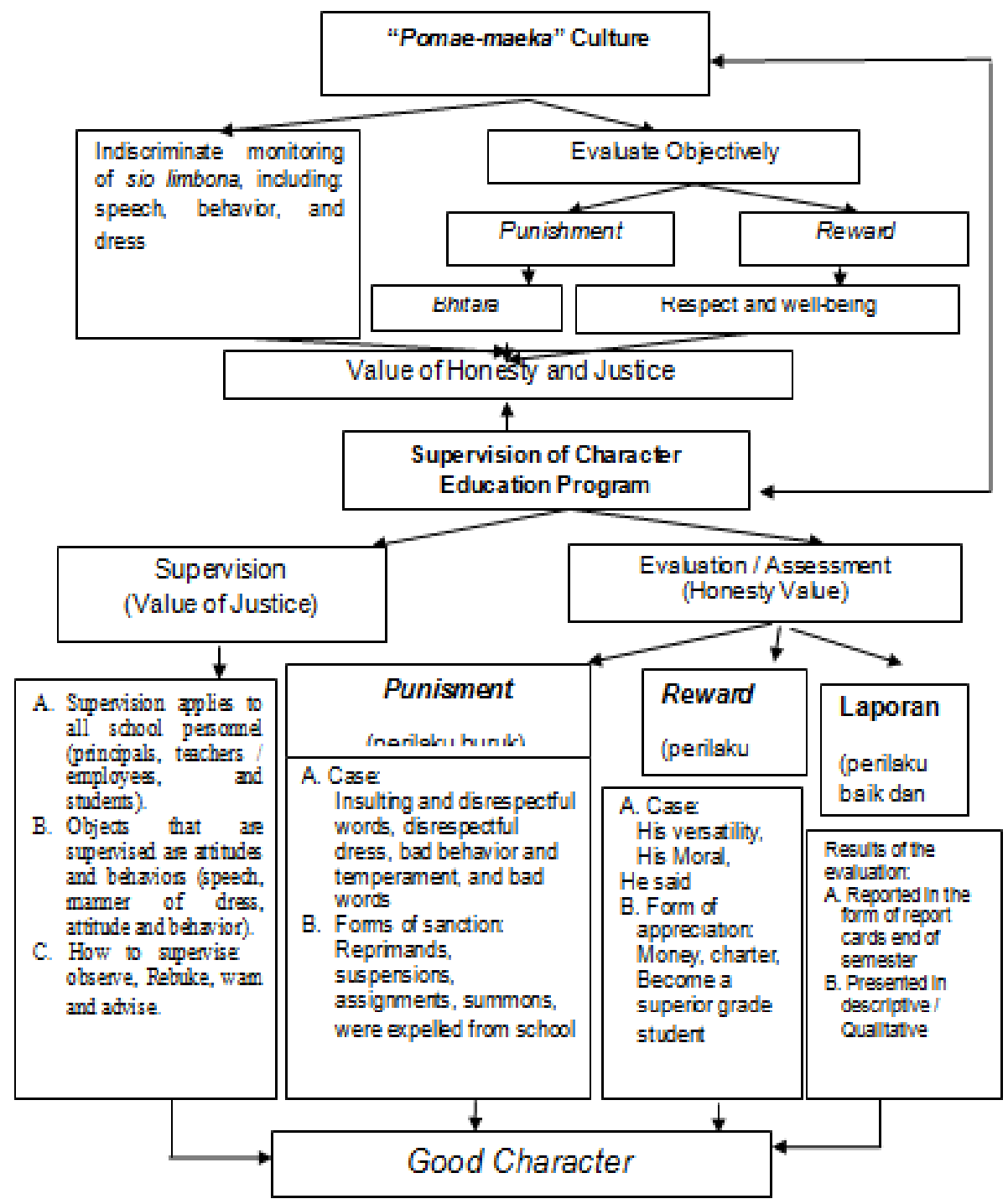

Figure 1. Flow Implementation of Cultural Values "pomae-maeka" in Monitoring and Evaluation of Character Education Program at SMAN 2 Baubau

\section{Discussion}

The key values in the culture "pomae-maeka", which is implemented under the supervision of the character education program, consist of (1) the value of justice, and (2) the value of honesty. First, the value of justice found in the surveillance system that performed continuously by the minister sio limbona applied to the general public both as implementing government or ordinary people is a surveillance system that adhered to the principle of fairness. Upholding justice in the oversight system is a rule in the "pomae-maeka" culture of Buton society. Justice is giving the rights of others equally (Mu'in, 2011: 224). Within the school community, such as at SMAN 2 Baubau, the value of justice in the culture "pomae-maeka" Buton has implemented in the monitoring and evaluation of character education. The enforcement of a supervisory system based on the principle of "fairness" can be found in the principal's manner of enforcing supervision to all school personnel (teachers / staff / employees and students). At SMAN 2 Baubau, more oversight on the object of how teachers educate values and students practice values. Implementation by way of observing the attitude and behavior of all school personnel, namely the principal himself, teachers / staff / employees, students, and principals themselves which includes attitude, speech, and how to dress. If the terms of the approach to supervision, the oversight in accordance with the culture of "pomae-maeka" committed both by the school principal or teacher is a supervisory approach clan control ie supervision approach conducted on the behavior of its personnel in accordance with the values, norms, customs, beliefs, customs Mores, other cultural aspects of the organization. Meanwhile, the terms of the authority on who is entitled to conduct surveillance, then how to control the value of education based on "culture pomae-maeka" at SMAN 2 Baubau using supervisory approach bureaucratic control ie supervision approach to the employee in accordance with the authority, duties, 
regulations, budget And policy (Schermerhorn, 2010: 465-466).The supervision authority of the character education program at SMAN 2 is owned by principals and teachers (homeroom teachers, BK teachers, religious teachers, teachers in the field of study). Supervision of students' behavior, attitude, and speech in SMAN 2 is done directly by principals and teachers. Such supervision ways also practiced by the sio limbona in the days of empire. Thus, the culture of "pomae-maeka" which has been practiced in character education programs in school is relevant to management theory. Monitoring carried out by the principal of the behavior of teachers, employees and students directly is an oversight that is top-down, ie supervision conducted direct superiors to subordinates. This supervision is done by a non-formal headmaster, who focuses more on personal awareness, self-introspection, and positioning himself as a role model for others. According to Athoillah (2010: 114), good supervision in the sense of coaching and empowerment. Such a supervisory system, aimed at all school personnel to be consistent and committed to the implementation of character education programs. Respect students practice values that teachers have taught, while teachers as value educators, consistent and committed to character education programs. While the principal gives exemplary values to be an example / curriculum of life for students and other school personnel.

Regular surveillance is conducted continuously in the classroom or at school by supervising, advising, admonishing, and reminding the school personnel the ways in which the sultanate society does. In the days of the empire minister limbona sio continuous monitoring, look at it day and night so that its structure is not exchanged. That is, the results of supervision can be used to perform corrective actions that must be done next. Is more directed to coaching or imposing sanctions. Principals with teachers and staff conduct routine and non-routine supervision, both formally and informally, are more encouraged by the reasons for taking corrective action as early as possible. Supervision of non-formal as in culture "pomae-maeka" as performed by the principal or teacher to students is more directed to non-formal oversight relaxed and friendly. The behavior of the leader in carrying out its functions in this way is said consideration behavioral structure. According Hemphil and Coons, structure consideration behavior is to give time to listen to the members of the group, being friendly and easy to approach, show friendship, trust and warmth in doing the job (Mukhtar, 2013: 32). The style of leadership behavior in carrying out its function is thus no other aim to obtain direct information so that if there is a deviation can be done corrective action as early as possible.

A leader in carrying out corrective action, required objectivity evaluation. Objectivity in the assessment is part of the culture "pomae-maeka" is to do an objective assessment, including speech, demeanor, the way people dress. Results of the assessment will have an effect on the provision of punishment or reward. That said, in the days of empire, punishment prosecuted through bhitara, while the reward in the form of state awards to people for good behavior / credited to the state. Second, value honesty in culture "tuturakana sara" was found in SMAN 2 Baubau on an objective assessment system based on standards that have been set. Honesty is a behavior based on an attempt to establish itself as a person who can always be trusted in words, actions, and work (Zubaedi, 2011: 74).

Character education evaluation includes how to behave, speak, how to dress the school personnel. Meanwhile, an assessment based on a standard assessment of objective and honest is the start of the determination of the parts valuation, determination of violation points, reward and punishment, the process of providing guidance to the reporting of results to the principal and parents of students, as well as the provision of value personality in Student report cards. Basically, in the implementation of this evaluation, the school takes corrective action against deviations and positive appreciation of the good. Assessment of good behavior, schools will reward. To reward outstanding students for the opportunity to study in a superior class free of charge, awards can also be charter and cash for well-behaved students, such as diligent libraries, cleanest class champions, and others. Reward system that applied to students is oriented towards humanity namely respect for human life as strengths.

Assessment of bad behavior, schools provide coaching or sanctions according to the severity of the problem. For students, sanctions can be assignment, suspension, parent calling, until expelled from school. Thus, an objective assessment system in SMAN 2 can have an effect on the award or punishment. According to Ivancevich et.al., the purpose of the evaluation feedback is motivating such reward in exchange for its excellent work and punishment to suppress unfavorable behavior (Ivancevich, Konopasche, Matteson, 2008: 171-175), the follow-up of the evaluation results, the establishment of reward and punishment) (Dharma Kesuma, CEPI Triatna, and Johar Permana, 2011: 45).

Meanwhile, the overall results of the evaluation of student behavior will determine the assessment results listed in the report in a qualitative / descriptive manner. Evaluation results of program implementation need to be made technical report honestly, transparently and openly. Technical reports regarding the implementation program and results (Aqib and Sujak, 2011: 83). The objectivity of character education evaluation / assessment is included in "personality values". The inclusion of good grades, very good or bad "personality values" in the report card is considered very important. If actual character education is considered as important as the importance of knowledge, then character education affects student's graduation. However, 
conditions like this in Indonesia are still not enforced nationally. Nonetheless, there are some schools that considers character values listed in the report cards as criteria for graduation / increase in students. Specifically, for schools where researchers conducted the study, these conditions have not been fully implemented.

Supervision and assessment conducted by the principle of free and fair is a learning management for school personnel and school institutions, as well as the hidden curriculum for learners that uphold honesty and fairness are very important and have a big influence on the change of behavior of students, school staff, and character of the school. Schools as an educational institution naturally able to put a value on honesty and fairness as collective consciousness at SMAN 2 Baubau. Without honesty all the components of the school it will be difficult to realize the school became the school of character. School that have character will produce students' character. Here, the evaluation function as indicated by Rohiat that "the results of the evalua can provide information that can be used to provide input to the overall SBM component, either in the context of input, process, output , and outcome of his" (Rohiat, 2010: 79).

\section{Conclusion}

From the description that has been presented, it can be concluded that the culture of community supervision Buton "pomae-maeka" contains the value of honesty and fairness. Both values in the culture "pomae-maeka" has been implemented under the supervision of character education. Supervision of character education programs that reflect cultural values not just implemented, but the most important is the commitment of all people in schools to practice in daily life. Schools must build the future of morals of children through the wisdom of the best, either in the past or the future .Commitment supervision of principals should be able to strengthen the understanding of the concepts ethical to really promote the moral development of the students. If so, then the school is the right vehicle to overcome the crisis this nation of character.

\section{References}

[1]. Aqib, Zainal and Sujak. Guide and Application Character Education for SD / MI, SMP / MTs, SMA / MA, SMK / MAK. Bandung: Yrama Widya 2011.

[2]. Athoillah, Anton. Management Basics . Bandung: Pustaka Setia 2010.

[3]. Bennett, William J., Finn, Chester E., Cribb, John TE The Educated Child. USA: The Fee Press, 1999.

[4]. Colgan, C. Making character education wo rk. American S c Hool Board Journal 1, Pp. 34-35. Retri eved October 8, 2008, f r o m ER I C dat a base.

[5]. Colquitt, Jason A., Jeffery A. Lepine, and Michael J. Wesson. Organizational Behavior, Improving Performance and comitment in the Workplace. New York: McGraw-: 2009.

[6]. Fukuyama, Francis. Trust: The Social Virtues and The Creation of Prosperity. New York: ffree Press Paperback, 1996

[7]. Huntington, Samuel P. Culture Count . In Lawrence E.Harrison (ED), Culture Matters, How Values Shape Human Progress . USA: Basic Books, 2000.

[8]. Culture Count, in Culture Matters . USA: Basic Books, 2000

[9]. Antarperadapan Conflict and the Future of World Politics, in translation Sadat Ismail. Yogyakarta Qalam 2003.

[10]. Ekosusilo, Madyo. Superior School-Based Value (Multikasus Studies at the SD / MA School 1, School Regia Pacis, and SMA Al Islam 01 Surakarta). Dissertation. Negeri Malang University, 2003.

[11]. Tiffany Gray, Character Education in Schools, essai : Vol. 7, Article 21.Available at: http://dc.cod.edu/essai/vol7/iss1/21 .

[12]. Hindaryatiningsih, Nanik. Application of Buton Cultural Values Values Education in Management (Ethnographic Study in SMAN 2 Baubau Southeast Sulawesi). Dissertation. Jakarta State University, 2013.

[13]. Ivancevich, Konopaske, Matteson, Organizational Behavior and Management, New York: McGraw-Hill, 2008.

[14]. Kesuma, Dharma, CEPI Triatna, and Johan Permana. Character Education Study of Theory and Practice in the School . Bandung: Youth Rosdakarya 2011.

[15]. Lickona, Thomas, Educating Character: How Our Schools Can Teach Respect and Responsibility. New York: Bantam Book, 1992.

[16]. Luddin, Muchlis R. No Choices Educations Education as a driver for Community Empowerment . Jakarta: Yayasan Mural 2005.

[17]. Muin, Fatchul. Character Education: Construction theoretical and practice . Yogyakarta: Ar-Ruzz Media 2011.

[18]. Mukhtar, Mukhneri. Supervision of Education . Jakarta: BPjM Press, 2013.

[19]. Rohiat. Primary School Management Theory and Practice . Bandung: Refika Aditama 2010.

[20]. Schermerhorn, John R. Introduction to Management. Asia: John Wiley \& Sons, Inc., 2010.

[21]. Spradley, James P. Participant Observation . New York: Holt, Rinehart and Winston, 1980.

[22]. Methods Ethnography, Misbah translation Zulfa Elizabeth.Yogyakarta: PT Tiara Discourse, 1997.

[23]. Suparno, Paul. Values Education in Schools and the problem, in the Education for Change, Education for Change: Continue Work Being Thanks , Eds. Elika Dwi Murwani dkk.Jakarta: BPK Gunung Mulia, 2010 .,

[24]. Rahim, A. Rahman. Top Values Culture Bugis . Yogyakarta: Waves 2011.

[25]. Rahyono, FX Wisdom Culture in Kata . Jakarta: Wedatamawidyasastra 2009.

[26]. Tamrin, US Cultural Dimensions Analysis Of The Philosophy Sara Pataanguna In Baubau. The International Journal of Social Sciences "Tijoss" Islamabad, Pakistan

[27]. V i adero, O. (2007). Proof of post i tive effect found for only a few character edu c ation pro grams. Educa tion W eek, 26. Retrieved November 7, 2008, from profess i onal Devel o pment Collect ion D ataba s e.

[28]. Zubaedi. Design Character Education Conception and Its Application in Education Institute . Jakarta: Kencana 2011.

[29]. http://www.rucharacter.org/file/practitioners_518.pdf 